\section{Reported Death}

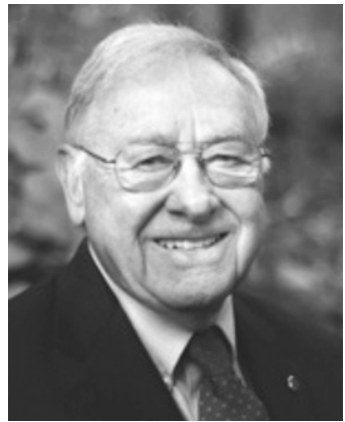

Charles E. Hess (1931-2019)

Dr. Charles E. Hess died on 13 Apr. 2019 at his home in Davis, CA, after a long illness surrounded by his family and beloved wife Eva of 38 years. Known by all as Charley, he had an ebullient spirit, a warm, outgoing personality, and a brilliant analytical mind. He influenced the lives of many; including students, colleagues, farmers, friends and family.

Charley was born on 20 Dec. 1931 in New Jersey. His father owned an ornamentals nursery and Charley grew up with a deep interest and love of plants. He had a brilliant career in horticulture research, university administration, and state, national, and international agricultural leadership.

Charley received his BS degree at Rutgers in 1953 and was awarded membership in Phi Beta Kappa. He received MS (1954) and $\mathrm{PhD}$ (1957) degrees at Cornell University in horticulture and plant physiology. From 1956 to 1958 he served as First Lieutenant and Project leader in the Crops Division, U.S. Army Biological Laboratories. He joined the Purdue Horticulture Department in 1958 as Assistant Professor and rose to the rank of Professor. He was well known for his research in rooting, rooting cofactors, and the development of the mungbean assay to evaluate rooting substances. In 1966, he returned to Rutgers as Research Professor and Chair of the Department of Horticulture, moved to higher administration, and in 1972 became the Founding Dean of Cook College, known today as the School of Environmental and Biological Sciences. In 1975, he accepted the position of Dean of the College of Agriculture of the University of California-Davis (UC-Davis) with a faculty appointment in the Department of Environmental Horticulture. In 1989, he was appointed by President George H.W. Bush and confirmed by the Senate, to be the Assistant Secretary for Science and Education in the United States Department of Agriculture where he served with distinction until 1991. He was appointed by President Ronald
Reagan to the National Science Board of the National Science Foundation where he promoted the funding of biotechnology research and its application to improve horticultural crops. He chaired the National Academy of Science committee to develop a national strategy for biotechnology in agriculture. $\mathrm{He}$ returned to UC-Davis as Director of International Programs and continued to hold positions as Chair of the Department of Nutrition and Vice Chancellor of Research.

Charley had a strong affiliation with two horticultural societies. He served as President of the American Society for Horticultural Science in 1973, and received the Society's highest honor as member of the Hall of Fame in 2013. He served as Editor and President of the International Plant Propagator's Society. He was awarded an honorary doctorate from Purdue in 1986.

Charles Hess had long been a major spokesperson for horticultural and agricultural science. He traveled widely with major efforts in Egypt and China. As a member of the Task force on Polar issues of the National Science Board he visited the Vanda Station in Antarctica where he was initiated in the Royal Lake Vanda Swim Club with a skinny dip! He was the father of five overachieving children and five beautiful grandchildren. He will be long remembered and missed.

Jules Janick 